\title{
How to Turn the Greek Deal into a Success
}

After weeks of negotiations and a dramatic summit in Brussels, the exit of Greece from the euro area has once again been averted. The Greek government has agreed not only to pass reforms demanded by the creditors under the old programme (and rejected by the Greek people in a referendum), but also to implement further cuts and structural reforms. In return, Greece is set to receive another loan programme from the European Stability Mechanism (ESM) - and possibly from the International Monetary Fund (IMF) as well - of more than $€ 80$ billion, which will be almost entirely used to service Greece's debt and to recapitalise its banks.

Yet, Greece is not out of the doldrums. Debt relief has not been granted, and it is difficult to find anyone who honestly believes that the country's problems will be solved with this package. Of the various issues which might go wrong, the German media has mostly focused on potential failures of the Greek government. For example, it is publicly questioned whether Prime Minister Alexis Tsipras will get a majority of the Greek parliament to approve the reforms (although he did so for the first packages to be voted upon), whether the Greek government will actually introduce legislation for the other reforms promised, and finally, whether Tsipras might be swept away in general elections by more populist forces before he can push through all that has been promised.

But even if the Greek government was extraordinarily efficient and effective at getting reform legislation passed and implemented, the agreement would most likely lead to failure. As a number of economists have been pointing out for quite a while, and as the IMF underlined in the debt sustainability analysis it published shortly before the Greek referendum in early July, the Greek public debt is not sustainable. In other words: Greece is insolvent.

In the private sector, "insolvent" means that a firm cannot service its debt over the long run, as its present and future liabilities are bigger than its present assets plus future profits. In such a situation, no simple change in the conduct of a firm can return it to solvency. It needs a restructuring of its liabilities. Insolvency for a national government is not as simple a concept, but it is usually understood as a situation in which plausible adjustments to economic and fiscal policies would fail to return a country to a sustainable debt level.

From this perspective, the agreement as it is now most widely interpreted is economically unsound. Its professed goal is to release Greece (at some point in the distant future) from funding through ESM/IMF programmes, yet if Greece is insolvent now, then by definition it cannot return to solvency - neither via its own actions (budget cuts and reforms) nor through additional loans. Additional austerity in such a situation - as currently demanded by Greece's creditors - will only lead to further output losses and more unemployment and will almost certainly fail to improve the country's debt sustainability.

Due to its unsustainable public debt, investors will shun Greece - even after a new round of reforms - because of the very real fear that their investment will be caught in a messy debt restructuring. Without a turnaround in private investment, economic growth will not pick up and the debt level will grow even more unsustainable. Greece will thus never be able to repay the loans now disbursed.

Yet, not all is lost. The agreement between Tsipras and his European partners contains the statement that while the Eurogroup "stresses that nominal haircuts on the debt cannot be undertaken", it nonetheless: 
stands ready to consider, if necessary, possible additional measures (possible longer grace and payment periods) aiming at ensuring that gross financing needs remain at a sustainable level ... conditional upon full implementation of the measures to be agreed in a possible new programme and [to be] considered after the first positive completion of a review.

While critics of the agreement have focused on the perceived strictness of the exclusion of "nominal haircuts", this wording in fact leaves a lot of room for manoeuvre. Changing the conditions of a loan is allowed (otherwise, the qualification "nominal" would not be necessary), and changes in these conditions can lower the net present value of the debt as much as is politically desired. To take an extreme example, if Greek debt were transformed into a perpetual loan at a zero per cent interest rate, this would effectively cancel the debt by rendering it economically meaningless.

Creditors could thus use this option to substantially reduce the net present value of the Greek debt by extending the maturity and lengthening the grace period. As the IMF points out in the latest update to its analysis of Greece's debt sustainability, this would take a massive extension of grace periods (the IMF speaks of 30 years), but it is completely feasible.

Sceptics might ask why one would need to reduce the net present value of Greek debt. They could point to the current debt service burden, which is already low - in fact, much lower than in Portugal or Italy. They could argue that Greece ought not to worry about the debt level now but should instead focus on reforms to get its economy growing again. Yet, this view is incomplete. The difference is in the outlook for investors. A clear commitment to bringing down the net present value of Greek debt would remove the sword of Damocles hanging over Greek private investments.

In order to reach such a shift in confidence, Greek debt would not necessarily need to be reduced until the Greeks show that they are willing to compromise. Instead, pre-defined levels of debt relief could be promised in return for specific reforms. This would not only create an incentive for the Greek government to push through real structural reforms (as opposed to mere austerity measures) but would also provide investors with the real possibility of a return to debt sustainability in Greece. The clear specification of reform targets and specific debt reductions is central to such a plan in order to minimise uncertainty. This is also the approach that has been used in the IMF and World Bank's Highly Indebted Poor Countries Initiative, through which two dozen of the most heavily indebted countries have seen their debt significantly reduced over the past two decades.

Is such a solution legal? While some in the German Finance Ministry have claimed that a reduction in the net present value of debt that one eurozone member owes other EU member states or institutions is already a violation of the no-bailout clause of the European treaties, other legal experts strongly dispute this. Moreover, the conditions for Greece's official loans were already adjusted without complaint during the first debt restructuring in 2012.

Is such a solution realistic? That very much depends on the leadership in Germany. The extension of grace periods by several decades would ignite a public debate about whether transfers to Greece are justified. Thus, the German leadership would have to be willing to spend political capital on pushing through such a solution. In return, they would have the chance to turn the Greek agreement into a success after all and finally end the euro crisis for good. The open question remains whether key players in Berlin actually want Greece to remain in the euro area. The conduct of German Finance Minister Wolfgang Schäuble during the negotiations has raised serious doubts about his intentions. It is now up to his boss, Chancellor Angela Merkel, to prove otherwise. 